\title{
Molecular based genetic diversity of Brongkol's superior durian germplasm of Semarang, Indonesia
}

\author{
CHRISTOPHER NICHOLAS YOSHUAKI PRAKOSO, AMIN RETNONINGSIH" \\ Department of Biology, Faculty of Mathematics and Natural Sciences, Universitas Negeri Semarang. Jl. Raya Sekaran, Semarang 50229, Central Java, \\ Indonesia. Tel./fax.: +62-813-16535512, ^email: aminretnoningsih2016@mail.unnes.ac.id
}

Manuscript received: 1 March 2021. Revision accepted: 11 November 2021.

\begin{abstract}
Prakoso CNY, Retnoningsih A. 2021. Molecular based genetic diversity of Brongkol's superior durian germplasm of Semarang, Indonesia. Biodiversitas 22: 5311-5316. Durio zibethinus is an Indonesian most popular edible durian. This species' genetic diversity is the highest compared to other durian species. Brongkol Village, Semarang, Indonesia is one of the villages that produce superior durian varieties. Brongkol durian is well-known for its sweet and bitter taste of aril with its white to yellow color. This research aimed to analyze the diversity and to identify superior durian in Brongkol using ISSR molecular markers. DNA was isolated from the leaves of 25 varieties of Brongkol superior durian. The DN A was isolated using a modified CTAB method. The genomic DNA was amplified using PCR employing 7 ISSR markers. The amplified DNA band was visualized using a 2\% agarose gel electrophoresis. Data were analyzed using the NTSYS' pc version 2.02 program. The alleles produced in this study were 340-3,000 bp in size. The Polymorphic alleles were found as much as $90.2 \%$. The results of study showed a similarity level of $0.29-0.95$. All of the Brongkol superior durians were identified as different varieties. All of the superior Brongkol durians studied were identified as distinct varieties. The results of this study indicated a high diversity of superior durian in Brongkol. In addition, specific alleles were found in varieties B5 and B16.
\end{abstract}

Keywords: Brongkol, superior durian, ISSR

\section{INTRODUCTION}

The diversity of species and genetics of durian in Indonesia is known to be the largest in the world. Twenty of 30 species of durian are found in Indonesia, especially in Kalimantan, where 14 species are endemic, and nine species are edible durian (Uji 2005; Santoso and Priyono 2015). Durio zibethinus is one of the most popular edible durians and is found in almost all archipelago regions. The genetic diversity of this durian species is known to be the highest compared to other species (Hikmah et al. 2016, Angeliena et al. 2019; Habibah et al. 2019; Songnuan et al. 2019; Hannum et al. 2020; Maranatha et al. 2020; Yursak et al. 2020). Each region in Indonesia has its own superior durian varieties identified by the aril's taste, color, and aroma. Yet, no more than 97 varieties of superior durian are registered at the Ministry of Agriculture (Balitbang Pertanian 2019). The number of registered superior durian varieties will continue to increase and new superior durian in various regions will be discovered. This durian germplasm data is one of the considerations for developing superior durian center.

Brongkol is a village in Jambu District, Semarang Regency, Central Java. The area is located at the foot of Mount Kelir at an altitude of 600-700 meters above sea level (masl). In addition to superior durian, Brongkol Village is also known for its superior coffee varieties. Superior durians from Brongkol had won several superior durian competitions in the Central Java Province (Latif 2013). The trading names for Brongkol durian generally use the name of the tree owner, the area's name, or other names. Hence, the genetic diversity of $D$. zibethinus in the area is known only from its name. Trees of different varieties of durian are challenging to distinguish from one another because the morphology of the vegetative organs is very similar. Therefore, cultivating certain superior durian varieties on a large scale requires identity certainty of superior varieties from the existing superior genetic diversity.

The genotype of superior Brongkol durian varieties can be ascertained through diversity analysis using molecular markers. Molecular markers provide more accurate genetic information than biochemical, cytological, or morphological markers. Isozyme biochemical markers are influenced by height differences (Fitmawati et al. 2017). Meanwhile, morphological markers are considered inaccurate because genetic and environmental factors determine the phenotypes. Environmental differences can affect the phenotype even though the genotype is the same (Handayani and Ismadi 2017). Molecular markers provide more accurate information about genetic relationships within and between different species (Ibarra-Torres et al. 2014; Patel et al. 2015). The advantages of molecular markers are that they are stable and not influenced by environmental factors (Yulita, 2013) and can be detected using DNA in all plant tissues (Kumar et al. 2006; Zulfahmi 2013; Zayed et al. 2014; Dasgupta et al. 2017).

One of the molecular markers often used to study genetic diversity is inter-simple sequence repeat (ISSR) (Vanijajiva 2012; Riupassa et al. 2015; Solikin et al. 2017; 
Siew et al. 2018; Angeliena et al. 2019). This marker is part of a microsatellite sequence that does not code for protein (non-coding region) and comprises one, two, or three nucleotides ( $\mathrm{Ng}$ and Tan 2015). ISSR is superior to RAPD (Cui et al. 2016; Daryono et al. 2019; Due et al. 2019). The advantages of this marker are high reproducibility, highly polymorphic, environmentally independent, cost-effective, and do not require the entire DNA sequence to design the primer (Jia et al. 2011; Thul et al. 2012; Animasaun et al. 2015; Sunar et al. 2016; Igwe et al. 2017). The ISSR sequence has high sensitivity and is easier to propagate by polymerase chain reaction (PCR) than RAPD (Due et al. 2019; Daryono et al. 2019). This study analyzed genetic diversity and identified superior Brongkol durian using ISSR molecular markers.

\section{MATERIALS AND METHODS}

The research subjects comprised of 25 superior durian varieties (code B1-B36) obtained from exploration and cultivation in Brongkol Village, Jambu Sub-district, Semarang District, Central Java Province, Indonesia. DNA amplification was performed using the peqSTAR $2 \mathrm{X}$ Thermocycler (Table 2) at the Research Laboratory and Molecular Biology Laboratory, Department of Biology, Faculty of Mathematics and Natural Sciences, the University of Negeri Semarang from January to December 2020. The stages of this research were (i) isolation of genomic DNA following Vanijajiva (2011) modified by Solikin et al. (2017), (ii) DNA amplification was done using 7 ISSR primers (Table 1), and (iii) visualization and analysis of amplified DNA fragments.

The ISSR PCR stages for Brongkol's superior durian consisted of pre-denaturation step at $95^{\circ} \mathrm{C}$ for 4 minutes, followed by a denaturation step at $95^{\circ} \mathrm{C}$ for 30 seconds, an annealing step of $44^{\circ} \mathrm{C}-53^{\circ} \mathrm{C}$ for 1 minute, and an extension at $72^{\circ} \mathrm{C}$ for 1 minute. A final extension terminated amplification at $72^{\circ} \mathrm{C}$ for 10 minutes. In addition, DNA multiplication by PCR was carried out for 35 cycles.

PCR results were migrated using electrophoresis on $2 \%$ agarose gel with a $100 \mathrm{bp}$ marker at 100 volts for 45 minutes. Each band that appears on the gel is an ISSR allele. The relative size of the allele refers to the $100 \mathrm{bp}$ marker. The allele for each variety is assigned a score of 1 if present and 0 if absent. Analysis of genetic diversity refers to the percentage of polymorphic alleles and the degree of similarity between superior durian varieties calculated using Similarity for Qualitative (SIMQUAL) with the DICE coefficient. Dendrogram construction was calculated using the UPGMA-SAHN NTSYSpc version 2.02 program (Rohlf 1998).

\section{RESULTS AND DISCUSSION}

\section{Brongkol's superior durian polymorphism}

DNA amplification of 25 superior durian varieties of Brongkol using 7 ISSR primers resulted in 36 alleles with a polymorphic allele percentage of $90.2 \%$ (Table 2 ).

Table 1. ISSR primer for analysis of superior durian diversity in Brongkol

\begin{tabular}{llc}
\hline \multicolumn{1}{c}{ Primers } & \multicolumn{1}{c}{ Sequences } & ${\text { Anneling temperature }\left({ }^{\mathbf{O}} \mathbf{C}\right)}$ \\
\hline ISSR4 & 5'-GAGGAGGAGGAGGAGAC-3 ' & 47.3 \\
ISSR5 & 5'-GAGGAGGAGGAGGAGAT-3 ' & 44.0 \\
ISSR10 & 5'-GTGTGTGTGTGTGTGTGTA-3 ' & 49.4 \\
PKBT2 & 5'-ACACACACACACACACTT-3 ' & 53.0 \\
PKBT7 & 5'-GAGAGAGAGAGAGAGAGAA-3 ' & 49.0 \\
PKBT9 & 5'-GAGAGAGAGAGAGAGAT-3 ' & 50.9 \\
PKBT12 & 5'-GTGTGTGTGTGTGTGTGTT-3 ' & 44.9 \\
\hline
\end{tabular}

Table 2. Polymorphism allele of 25 superior durian varieties of Brongkol using 7 ISSR primers

\begin{tabular}{|c|c|c|c|c|c|}
\hline Primers & $\begin{array}{l}\text { Relative size } \\
\text { (bp) }\end{array}$ & $\begin{array}{c}\text { Number of } \\
\text { alleles }\end{array}$ & $\begin{array}{c}\text { Number of } \\
\text { polymorphic alleles }\end{array}$ & $\begin{array}{c}\text { Number of } \\
\text { monomorphic alleles }\end{array}$ & $\begin{array}{c}\text { Percentage of polymorphic } \\
\text { alleles }(\%)\end{array}$ \\
\hline ISSR4 & $500-1200$ & 4 & 3 & 1 & 75.0 \\
\hline ISSR5 & $600-1500$ & 3 & 3 & 0 & 100.0 \\
\hline ISSR10 & $500-940$ & 4 & 4 & 0 & 100.0 \\
\hline PKBT2 & $340-1500$ & 11 & 9 & 2 & 81.8 \\
\hline PKBT7 & $750-3000$ & 6 & 6 & 0 & 100.0 \\
\hline РКBT9 & $370-940$ & 4 & 4 & 0 & 100.0 \\
\hline PKBT12 & $550-1500$ & 4 & 3 & 1 & 75.0 \\
\hline Total & & 36 & 32 & 4 & \\
\hline Average & & & & & 90.2 \\
\hline
\end{tabular}


The highest number of alleles was found in PKBT2 primers, namely 11 alleles measuring 340-1500 bp. The resulting allele size ranged from $340-3000 \mathrm{bp}$. The size of the ISSR allele was generally between $250-2000$ bp ( $\mathrm{Ng}$ and Tan 2015). Alleles of $>2000 \mathrm{bp}$ sizes were only found in PKBT7 primers in two varieties. Alleles of $>2000 \mathrm{bp}$ sizes were also found in the study by Sembiring et al. (2015). Two possible causes for the appearance of this allele are because of the contaminated DNA (Patramurti et al. 2014), and the concentration of $\mathrm{MgCl}_{2}$ was too high when the PCR was conducted (Pharmawati 2009), or the accessions studied had new unique alleles. Each primer produced several alleles of varying sizes. This variation is due to differences in the nucleotide-based sequence of the primers and the interactions between the primers and DNA. The number of accessions studied can affect the number of alleles because the more accessions studied, the greater the chance for new alleles to emerge (Retnoningsih et al. 2011; 2016). The difference in the number of alleles found presumably happened due to differences in geographic areas that affect the genetic diversity of durians. Allele polymorphism in this study was higher than Thailand durian Vanijajiva (2012), but lower than Kundur Island durian (Angeliena et al. 2019). The higher number of polymorphic alleles in Brongkol durian indicates that the durian in Nonthaburi Province has more limited genetic diversity than the superior durian in Brongkol. The ISSR4 and ISSR5 primers produced almost the same number of alleles as the Vanijajiva analysis (2012), the same as PKBT7, whose results were similar to Angeliena et al. (2019).

ISSR markers have been shown to reveal and produce high polymorphic alleles (Siew et al. 2018; Due et al. 2019). The high polymorphic allele in durian is due to the open and random cross-pollination mechanism (Handayani 2016). Biological factors of pollination affect the genetic diversity of durian plants. Pollination by different tree pollen will increase the variety in the offspring. Durian flowers are hermaphrodite, which allows self-pollination. One of the barriers that prevent self-pollination is selfincompatibility (Bumrungsri et al. 2009). Several studies showed that Durio's pollination is assisted by a group of animals such as birds, bats, and insects (Yumoto 2000; Sheema et al. 2017; Wayo et al. 2018; Chaiyarat et al. 2019). Another factor that influences genetic variation is mutation. Mutations in repeated sequences tend to be higher (Udupa and Baum 2001). Mutations that result in the exchange of DNA base chains will cause changes in phenotypic or genotypic traits (Chahal and Gosal 2006). The environment also influences morphological changes. Different environments can produce various morphological features (Wang et al. 2012). Brongkol superior durian has high genetic diversity because each tree generally comes from seed germination, so that it can be ascertained that it has different genotypes. The genotype of the vegetatively propagated seedlings is relatively the same as the parent because there is no gene flow.

\section{The molecular identity of Brongkol superior durian}

The amplification of Brongkol's superior durian DNA using ISSR primers produced several specific alleles (Table $3)$. The presence of specific alleles can determine plant identity. Specific alleles, if present in certain genes, allow a unique phenotype of a plant. B5 variety has the most specific alleles. Specific alleles for the B5 variety were found in ISSR4 primers measuring $1200 \mathrm{bp}$, PKBT2 primers measuring $1200 \mathrm{bp}$, and primers PKBT12 at a size of $1500 \mathrm{bp}$. Another variety that has a specific allele is B16. The B16 variety is locally known as durian Aziz. Specific alleles for the B16 variety were only found in PKBT2 primers measuring $1500 \mathrm{bp}$. The specific allele found in the B5 variety is not known for its unique morphological characteristics, yet it shows arilus with orange yellow color based on information from the farm owner. Specific alleles in PKBT2 primers were also found by Solikin et al. (2017), namely in Petruk durian on an allele measuring $450 \mathrm{bp}$, and Angeliena et al. (2019) on an allele of $410 \mathrm{bp}$. Other specific alleles were found in PKBT12 primers on HM and GT of 1500 bp size (Angeliena et al. 2019). Specific alleles are important as accurate and stable markers useful for the commercial development of durian varieties (Riupassa et al. 2015). Another use of particular alleles is in developing Sequence Characterized Amplified Region (SCAR) markers for molecular identification at the variety level (Cui et al. 2016).

\section{Similarity analysis of superior Brongkol durian}

The UPGMA-based dendrogram shows that 25 superior durian varieties of Brongkol have a similarity coefficient of 0.29 to 0.95 and produced two main clusters (Figure 1). Cluster I consisted of 19 varieties (B1-B29) (76\%), and Cluster II consisted of 6 varieties (B16-B31) (34\%). Cluster I was grouped into two sub-clusters in 18 varieties (B1, B5, B8, B9, B11, B15, B14, B22, B23, B32, B24, $\mathrm{B} 26, \mathrm{~B} 36, \mathrm{~B} 21, \mathrm{~B} 34, \mathrm{~B} 4, \mathrm{~B} 3$, and B19) and 1 Durian belonged to variety B29. Cluster II was classified into two sub-clusters: Durian B16 and five other varieties (B7, B20, B28, B30, and B31).

Table 3. Specific alleles in some Brongkol superior durian varieties

\begin{tabular}{lccc}
\hline \multirow{2}{*}{ Variety } & \multicolumn{3}{c}{ Relative size (bp) } \\
\cline { 2 - 4 } & ISSR4 & PKBT2 & PKBT12 \\
\hline B5 & 1200 & & \\
B16 & & 1500 & \\
B5 & & 1200 & 1500 \\
B5 & & & \\
\hline
\end{tabular}




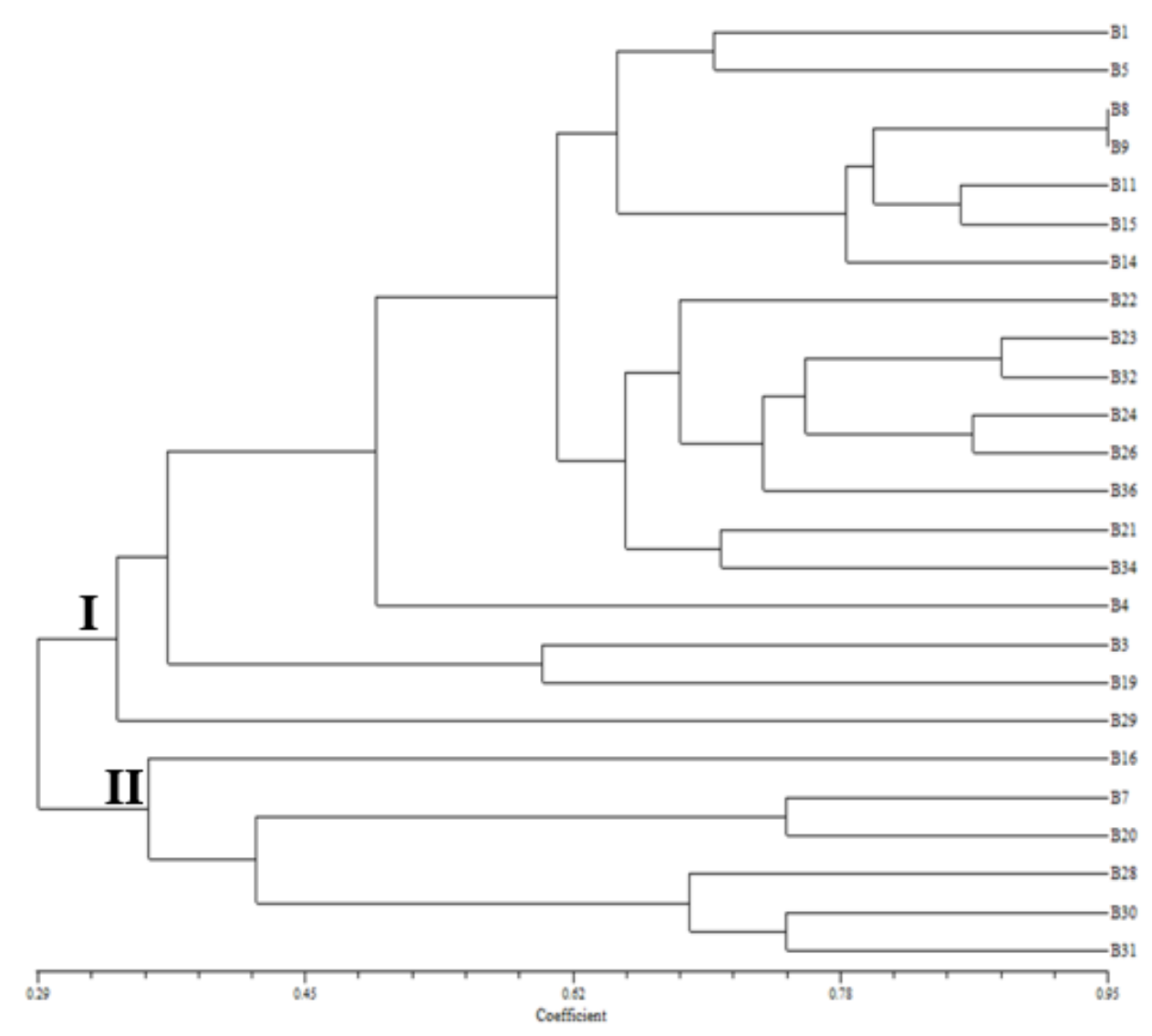

Figure 1. Dendrogram 25 superior varieties of Brongkol durian

The highest similarity coefficient (0.95) was found between varieties B8 and B9. The similarity coefficient and dendrogram show that the higher the similarity coefficient, the lower the genetic distance. Varieties in one group show high genetic similarity (Kristamtini et al. 2014). A similarity value of more than 0.70 indicates high similarity (Singh 1999), and if it is less than 0.60, it is classified as low (Trimanto 2012). The profile of durians from the same cluster tends to be similar (Yulita and Murnianjari 2010). Accessibility affects the level of genetic diversity (Alcantara et al. 2017). Some of the varieties obtained from the same area are not in the same cluster or sub-cluster; because, according to Tacca et al. (2004) and Jose et al. (2005), genotypes originating from the same area are not always in the same group. The grouping of samples into one cluster indicates high similarity between the DNA loci (Yulita 2013). Overall, the dendrogram showed no durian varieties had $100 \%$ similarity value. All Brongkol select durian varieties reviewed in this research had different genetic profiles from one another. This dendrogram strengthens the fact that the durian trees in the Brongkol area are derived from seed/sexual propagation. Brongkol durians are mostly superior, so that they have the potential to become new varieties if a distinctive marker is found; the samples studied include Brongkol's flagship durian, superior and limited in number. Other varieties generally do not have unique taste and color like the Brongkol's durian.
In conclusion, the genetic diversity of 25 superior durian varieties of Brongkol revealed by using 7 ISSR primers was high, with a percentage of polymorphic alleles of $90.2 \%$. All the durian samples analyzed showed different varieties because there were not $100 \%$ similar to the varieties. This study also found specific alleles in B5 variety in ISSR4 primers measuring $1200 \mathrm{bp}$, PKBT2 primers measuring $1200 \mathrm{bp}$, PKBT12 primers at $1500 \mathrm{bp}$ sizes, and particular alleles for B16 varieties on PKBT2 primers measuring $1500 \mathrm{bp}$.

\section{ACKNOWLEDGEMENTS}

Profound gratitude is given to the Head of Biology Laboratory of the Universitas Negeri Semarang for allowing us to use the laboratory facilities and Brongkol durian farmers for permitting their durian plants to be researched.

\section{REFERENCES}

Alcantara RBF, Silva AVC, Blank AF, Almelda CS, Carvalho SVA, Blank A. 2017. Analysis of genetic diversity of Hyptis pectinata (L.) Poit. plants using ISSR markers. Genet Mol Res16 (3): 1-10. DOI: $10.4238 / \mathrm{gmr} 16039603$.

Angeliena A, Ma'ruf A, Sidiq, HA, Anggraito, YU, Habibah NA, Huyop FZ, Retnonigsih A. 2019. The diversity of superior Indonesia Durians 
based on molecular markers. AIP Conference Proceedings 2155 (1): 020043-1-020043-7. DOI: 10.1063/1.5125547.

Animasaun DA, Morakinyo JA, Krishnamurthy, R. 2015. Assessment of genetic diversity in accessions of pearl millet (Pennisetum glaucum) and napier grass (Pennisetum purpureum). Iran J Genet Plant Breed 4 (1): 25-35.

Badan Penelitian dan Pengembangan Pertanian. 2019. Bimbingan Teknis Durian 2019. http://balitbu.litbang.pertanian.go.id/index.php/beritamainmenu-26/13-info-aktual/1313-bimbingan-teknis-durian-2019 [Indonesian]

Bumrungsri S, Sripaoraya E, Chongsiri T, Sridith K, Paul A, Racey. 2009 The pollination ecology of durian (Durio zibethinus, Bombacaceae) in southern Thailand. J Trop Ecol 25: 85-92. DOI: $10.1017 / \mathrm{S} 0266467408005531$

Chahal GS, Gosal SS. 2006. Mutation Breeding. In: Principles and Procedures of Plant Breeding. Biotechnology and Conventional Approaches. Alpha Science International. Ltd., Oxford.

Chaiyarat R, Boonma W, Koedrith P. 2019. The role of pteropodid bats in pollination of durian (Durio zibethinus) in managed orchards in suburban habitat of Thailand. Urban Ecosyst 23: 97-106. DOI: 10.1007/s11252-019-00919-w.

Cui C, Li Y, Liu Y, Li X, Luo S, Zhang Z, Wu R, Liang G, Sun J, Peng J, Tian P. 2016. Determination of genetic diversity among Saccharina germplasm using ISSR and RAPD markers. CR Biologies 340 (2): 76-86. DOI: 10.1016/j.crvi.2016.11.005.

Daryono BS, Subiastuti AS, Fatmadanni A, Sartika D. 2019. Phenotypic and genetic stability of new Indonesian melon cultivar (Cucumis melo L. 'Melonia') based on ISSR markers. Biodiversitas 20 (4): 10691075. DOI: $10.13057 /$ biodiv/d200419.

Dasgupta N, Nandy P, Sengupta C, Das S. 2017. Genetic variation in relation to adaptability of three mangrove species from the Indian Sundarbans assessed with RAPD and ISSR markers. J For Res 29: 301-310. DOI: 10.1007/s11676-017-0467-7.

Due MS, Susilowati A, Yunus A. 2019. The Effect of gamma rays irradiation on diversity of Musa paradisiaca var. sapientum as revealed by ISSR molecular marker. Biodiversitas 20 (5): 1416-1422. DOI: $10.13057 / \mathrm{biodiv} / \mathrm{d} 200534$.

Fitmawati, Damayanti A, Herman. 2017. Studi komparasi karakter morfologi dan isozim duku Lansium parasiticum (Osbeck) K.C. Sahni \& Bennet asal Kabupaten Kuantan Singingi, Riau. Buletin Kebun Raya 20 (2): 89-102. [Indonesian]

Habibah NA, Anggraito YU, Abdullah M, Sidiq HA, Angeliena A, Ma'ruf A, Huyop F, Retnoningsih A. 2019. Morphological-based diversity analysis of durian from Kundur Island, Indonesia. Intl Conf Biosci Med Engineer, Bali, Indonesia, 11-12 April 2019.

Handayani F, Wulandari RA, Murti RH. 2016. Genomic DNA extraction method from mature leaf of lai (Durio kutejensis Becc.). Agrivita 38 (1): 73-79. DOI: 10.17503 /agrivita.v38i1.659.

Handayani S, Ismadi. 2017. Inventory and morphological characterization of durian (Durio zibethinus) in Langkahan and Sawang Sub-District of North Aceh Indonesia. Proceedings of MICoMS 2017, Emerald Publishing Limited, Bingley. DOI: 10.1108/978-1-78756-793-100027.

Hikmah RU, Retnoningsih A, Habibah NA. 2016. Keragaman durian berdasarkan fragment internal transcribed spacers (ITS) DNA ribosomal melalui analisis PCR-RFLP. Jurnal MIPA 39 (1): 11-18 [Indonesian]

Ibarra-Torres P, Valadez-Moctezuma E, Perez-Grajales M, RodríguezCampos R, Jaramillo-Flores ME. 2014. Inter- and intraspecific differentiation of Capsicum annuum and Capsicum pubescens using ISSR and SSR markers. Sci Hortic 181: 137-146. DOI: 10.1016/j.scienta.2014.10.054

Igwe DO, Afiukwa CA, Ubi BE, Ogbu KI, Ojuederie OB, Ude GE. 2017. Assessment of genetic diversity in Vigna unguiculata L. (Walp) accessions using intersimple sequence repeat ( ISSR ) and start codon targeted ( SCoT ) polymorphic markers. BMC Genet 18: 98. DOI: 10.1186/s12863-017-0567-6.

Jose RJ, Rozzi FR, Sardi M, Abadias NM, Hernandez M, Puciarelli. 2005. Functionalcranical approach to the influence of economic strategy on skull morphology. Am J Phys Anthropol 128: 757-771. DOI 10.1002/ajpa.20161

Jia XD, Wang T, Zhai M, Li Y, Guo Z. 2011. Genetic diversity and identification of Chinese-grown pecan using ISSR and SSR Markers. $\begin{array}{llll}\text { Molecules } & 16 & (12): & 10078-10092 .\end{array}$ 10.3390/molecules161210078.
Kristamtini, Taryono, Basunanda P, Murti RH. 2014. Keragaman genetik kultivar padi beras hitam lokal berdasarkan penanda mikrosatelit. Jurnal AgroBiogen $10 \quad$ (2): 69-76 DOI: 10.21082/jbio.v10n2.2014.p69-76. [Indonesian]

Kumar S, Prasad KV, Choudhary ML. 2006. Detection of genetic variability among Chrysanthemum radio mutants using RAPD markers. Curr Sci Assoc 90 (8): 1108-1113.

Latif NE. 2013. Identifikasi morfologi durian (Durio zibethinus) Sunan dan Brongkol dalam penyusunan basis data keragaman. Jurnal Agroteknologi 122: 7-8. [Indonesian]

Maranatha CR, Koimah N, Artika J. 2020. Keanekaragaman morfologi durian lokal (Durio zibethinus Murr) di Aceh Tamiang, Indonesia. Prosiding Seminas Nasional Peningkatan Mutu Pendidikan 1 (1): 357-360. [Indonesian]

Ng WL, Tan SG. 2015. Inter Simple Sequence Repeat (ISSR) marker: Are we doing it right?. ASM Sci J 9 (1): 30-39.

Patel HK, Fougat RS, Kumar S, Mistry JG, Kumar M. 2015. Detection of genetic variation in Ocimum species using RAPD and ISSR markers. 3 Biotech 5 (5): 697-707. DOI: 10.1007/s13205-014-0269-y.

Patramurti C, Sugiyanto, Nurrochmad A, Martono. 2014. Polymorphism of cytochrome P450 2A6 (CYP2A6*1 and CYP2A6*4) among Javanese Indonesian smoker and non smoker. Indonesian J Pharm 26 (1): 11-19. DOI: 10.14499/indonesianjpharm26iss1pp11.

Pharmawati M. 2009. Optimalisasi ekstraksi DNA dan PCR RAPD pada Grevillea spp. (Proteaceae). Jurnal Biologi 13: 12-16. [Indonesian]

Retnoningsih A, Megia R, Hartana A. 2011. Microsatellite markers for classifying and analyzing genetic relationship between banana cultivars in Indonesia. Acta Horticulturae 897: 153-160. [Indonesian]

Retnoningsih A, Rahayu ES, Sari IP. 2016. Characterization of local durian germplasm based on the morphology of fruit. Jurnal Sains dan Teknologi 14 (2): 89-94. [Indonesian]

Riupassa PA, Chikmawati T, Miftahudin, Suharsono. 2015. The molecular diversity-based ISSR of Durio tanjungpurensis originating from West Kalimantan, Indonesia. Makara J Sci 19: 27-36. DOI: 10.7454/mss.v19i1.4479.

Rohlf FJ. 1998. NTSYS-pc Version. 2.02i Numerical Taxonomy and Multivariate Analysis System. Applied Biostatistics Inc. Setauket, New York.

Santoso PJ, Priyono A. 2015. Potensi dan status pengembangan tiga kerabat durian: Lai, Mandong, dan Kerantungan. Iptek Hortikultura 11: 31-37. [Indonesian]

Sembiring MB, Rahmi D, Maulina M, Tari V, Rahmayanti R, Suwardi AB. 2015. Identifikasi karakter morfologi dan sensoris kultivar mangga (Mangifera indica L.) di Kecamatan Langsa Lama, Aceh, Indonesia. Jurnal Biologi Tropis 20 (2): 179-184. DOI: 10.29303/jbt.v20i2.1876.

Sheema A, Clements G, McConkey K, Sritongchuay T, Pathil S, Yazid MNHA, Campos-Arceiz A, Forget PM, Bumrungsri S. 2017. Pollination by the locally endangered island flying fox (Pteropus hypomelanus) enhances fruit production of the economically important durian (Durio zibethinus). Ecol Evol 7 (21): 8670-8684. DOI: $10.1002 /$ ece3.3213.

Siew GY, Ng WL, Tan SW, Alitheen NB, Tan SG, Yeap SK. 2018 Genetic variation and DNA fingerprinting of durian types in Malaysia using simple sequences repeat (SSR) markers. PeerJ 6: e4266. DOI: $10.7717 /$ peerj. 4266

Singh G. 1999. Plants Systematics. Science Publisher, Inc. New Hampshire.

Songnuan W, Pichakum A, Traiperm P, Rungjangsuwan E, Siriwattanakul U, Leeratsuwan N, Chareonsap PP, Kulpradit K, Somsri S, Swangpol SC. 2019. Diversity of durian (Durio zibethinus) from Nonthaburi, Thailand based on morpho-palatability characteristics and simple sequence repeat markers. Agric Nat Resour 53: 218-227.

Solikin A, Retnoningsih A, Rahayu ES. 2017. Karakterisasi aksesi durian lokal Hortimart Agro Centre Jawa Tengah menggunakan penanda molekuler inter simple sequence repeats (ISSR). Floribunda 5 (7): 267-276. DOI: 10.32556/floribunda.v5i7.2017.189. [Indonesian]

Sunar S, Yildirim N, Sengul M, Agar G, 2016. Genetic diversity and relationships detected by ISSR and RAPD analysis among Aethionema species growing in Eastern Anatolia (Turkey). Comptes Rendus Biol 339 (34): 147-151. DOI: 10.1016/j.crvi.2016.02.006.

Tacca JA, Abad RG, Bastian STJ. 2004. Molecular characterization and relationships of 14 Durian cultivars (Durio zibethinus Murr.) using RAPD markers. Philippine J Crop Sci 30: 20-25.

Thul ST, Darokar MP, Shasany AK, Khanuja SPS. 2012. Molecular profiling for genetic variability in Capsicum species based on ISSR 
and RAPD Markers. Mol Biotechnol 51 (2): 137-147. DOI: 10.1007/s12033-011-9446-y.

Trimanto. 2012. Karakterisasi dan jarak kemiripan uwi (Dioscorea alata L.) berdasarkan penanda morfologi umbi. Buletin Kebun Raya 15 (1): 47-59. [Indonesian]

Udupa S, Baum M. 2001. High mutation rate and mutation bias at (TTA)n, microsatellite loci in chickpea (Cicer arientenum L.). Mol Gen Genomics 265 (6): 1097-1103. DOI: 10.1007/s004380100508.

Uji T. 2005. Keanekaragaman jenis dan sumber plasma nutfah durio (Durio spp.) di Indonesia. Buletin Plasma Nutfah 11 (1): 28-33. [Indonesian]

Vanijajiva O. 2011. Genetic variability among durian (Durio zibethinus Murr.) cultivars in the Nonthaburi Province, Thailand detected by RAPD analysis. J Agric Technol 7(4): 1107-1116.

Vanijajiva O. 2012. The application of ISSR markers in genetic variance detection among durian (Durio zibethinus Murr.) cultivars in the Nonthaburi province, Thailand. Procedia Engineering 32: 155-159. DOI: $10.1016 /$ j.proeng.2012.01.1250.

Wang Y, Wang X, Paterson AH. 2012. Genome and gene duplications and gene expression divergence: a view from plants. Ann New York Acad Sci 1: 1-14. DOI: 10.1111/j.1749-6632.2011.06384.x

Wayo K, Phankaew C, Stewart AB, Bumrungsri S. 2018. Bees are supplementary pollinators of self-compatible chiropterophilous durian. J Trop Ecol 34: 41-52. DOI: 10.1017/S0266467418000019.
Yulita KS, Murnianjari. 2010. Keragaman genetik beberapa klon durian (Durio zibethinus Murray) asal Jawa Barat berdasarkan sidik Random Amplified Polimorphic DNA. Berita Biologi 10 (3): 269-275. DOI: 10.14203/beritabiologi.v10i3.741. [Indonesina]

Yulita KS. 2013. Identifiikasi molekuler pohon induk beberapa varietas durian asal Jepara menggunakan Random Amplified Polymorphic DNA. Jurnal Hortikultura 23 (2): 99-106. DOI: 10.21082/jhort.v23n2.2013.p99-106.

Yumoto T. 2000. Bird-pollination of three Durio species (Bombacaceae) in a tropical rainforest in Sarawak, Malaysia. Am J Bot 87: 11811188. DOI: $10.2307 / 2656655$.

Yursak Z, Amanda UD, Widiyastuti D, Susilawati PN. 2020. Morphological characterization of local durian of Banten Province, Indonesia. IOP Conf Series Earth Environ Sci 591: 1-9. DOI: 10.1088/1755-1315/591/1/012048.

Zayed MZ, Ho WS, Pang LS, Ahmad FB. 2014. EMS-induced mutagenesis and DNA polymorphism assessment through ISSR markers in Neolamarckia cadamba (kelampayan) and Leucaena leucocephala (petai belalang). Eur J Exp Biol 4 (4): 156-163.

Zulfahmi. 2013. Penanda DNA untuk analisis genetik tanaman. Jurnal Agroteknologi 3 (2): 41-52. DOI: 10.24014/ja.v3i2.87. [Indonesian] 